\title{
Assessment of Free and Total Cyanide Levels in the Water Environment of Shatt Al-Arab
}

\author{
Zuhair Ali Abdulnabi \\ Department of Marine Chemistry, Marine Science Center, University of Basrah, Basra, Iraq
}

\section{* Corresponding author:}

tel: $+96440-7703112882$

email: zuhir38@yahoo.com

Received: July 6, 2019

Accepted: September 23, 2019

DOI: $10.22146 /$ ijc.47369

\begin{abstract}
The concentration of free and total cyanide in waters was measured by using the colorimetric method through complex formation with pyridine-barbituric acid at the wavelength of $578 \mathrm{~nm}$. Ten stations were selected from water surfaces in the south of Iraq. The samples were distributed among two stations, one was on Euphrates River and the other was on Tigris River (before their confluence and formatting of Shatt Al-Arab) and selected seven stations along Shatt Al-Arab River. All the samples were collected from surface water at depth of 10-15 cm and their $\mathrm{pH}$ was adjusted to 12 by using sodium hydroxide. The results showed the highest concentration of free cyanide $(0.254 \mathrm{mg} / \mathrm{L})$ in station $W_{7}$ and the lowest concentration in stations $W_{2}, W_{9}$ and $W_{10}$, while the highest and lowest concentration of total cyanide $(9.962,0.207 \mathrm{mg} / \mathrm{L})$ were recorded in station $W_{7}$ and $W_{1}$ respectively. The standard deviation of all sites $(n=3)$ of free and total cyanide was calculated and showed 0.007-0.048 and 0.001-0.042 ranges respectively. Furthermore, some of the physico-chemical properties of water were recorded in these stations.
\end{abstract}

Keywords: colorimetric method; free cyanide; total cyanide; conductometric titration

\section{- INTRODUCTION}

Cyanide has a single negative charge. It consists of carbon and nitrogen atoms with triple covalent bonds $-(\mathrm{C} \equiv \mathrm{N})^{-}$. It refers to the $\mathrm{CN}$ groups in cyanide compounds that can be determined as the cyanide ion. Cyanide is a highly reactive compound which readily forms metal cyanide complexes and organic compounds in water. The chemical composition of cyanide in environment samples is affected by factors such as $\mathrm{pH}$, temperature, trace metal content, and the presence of sulfur or sulfur compounds [1-3]. Many cyanide species can exist in aquatic systems such as free cyanide $\left(\mathrm{CN}^{-}\right.$, $\mathrm{HCN}$ ), simple cyanide compounds that can exist in soluble form $(\mathrm{NaCN}, \mathrm{KCN})$ and relatively insoluble $\left.\left(\mathrm{Zn}(\mathrm{CN})_{2}, \mathrm{Cu}(\mathrm{CN})_{2}\right)\right)$, weak metal cyanide $\left(\left(\mathrm{Zn}(\mathrm{CN})_{4}\right)^{2-}\right.$, $\left.\left(\mathrm{Cd}(\mathrm{CN})_{4}\right)^{2-}\right)$, moderately strong metal-cyanide complexes $\left(\left(\mathrm{Cu}(\mathrm{CN})_{2}\right)^{-},\left(\mathrm{Cu}(\mathrm{CN})_{3}\right)^{2-}\right.$ and $\left.\left(\mathrm{Ni}(\mathrm{CN})_{4}\right)^{2-}\right)$ and strong metal cyanide complexes $\left(\left(\mathrm{Fe}(\mathrm{CN})_{6}\right)^{4-}\right.$, $\left.\left(\mathrm{Co}(\mathrm{CN})_{6}\right)^{4-}\right)$ [1,4-5]. Moreover, all cyanide compounds have toxic properties especially the free cyanide species [6-7] and their increase causes a lot of risks on the aquatic system and thus affects human and animal health because they rapidly transfer to all organs and tissues and accumulate via blood. The cyanide concentration is higher in red blood cells than in plasma by a factor of two or three, reflecting cyanide's tendency to bind with methaemoglobin. Cyanide may also accumulate in body cells by binding with metalloproteins or enzymes such as catalyses or cytochrome $c$ oxidase [8-10]. The most important sources of cyanide pollution in the surface water is through mining operations and industrial and agricultural activities [5,10-11]. Thus this study focuses on the evaluation of free and total cyanide levels and their concentrations and distribution in water in order to know the sources of contaminants in the aquatic system.

\section{- EXPERIMENTAL SECTION}

\section{Description of the Study Area}

Ten stations were chosen from water surfaces of different regions along the Basra governorate as shown in Fig. 1. The samples were collected from one station on 


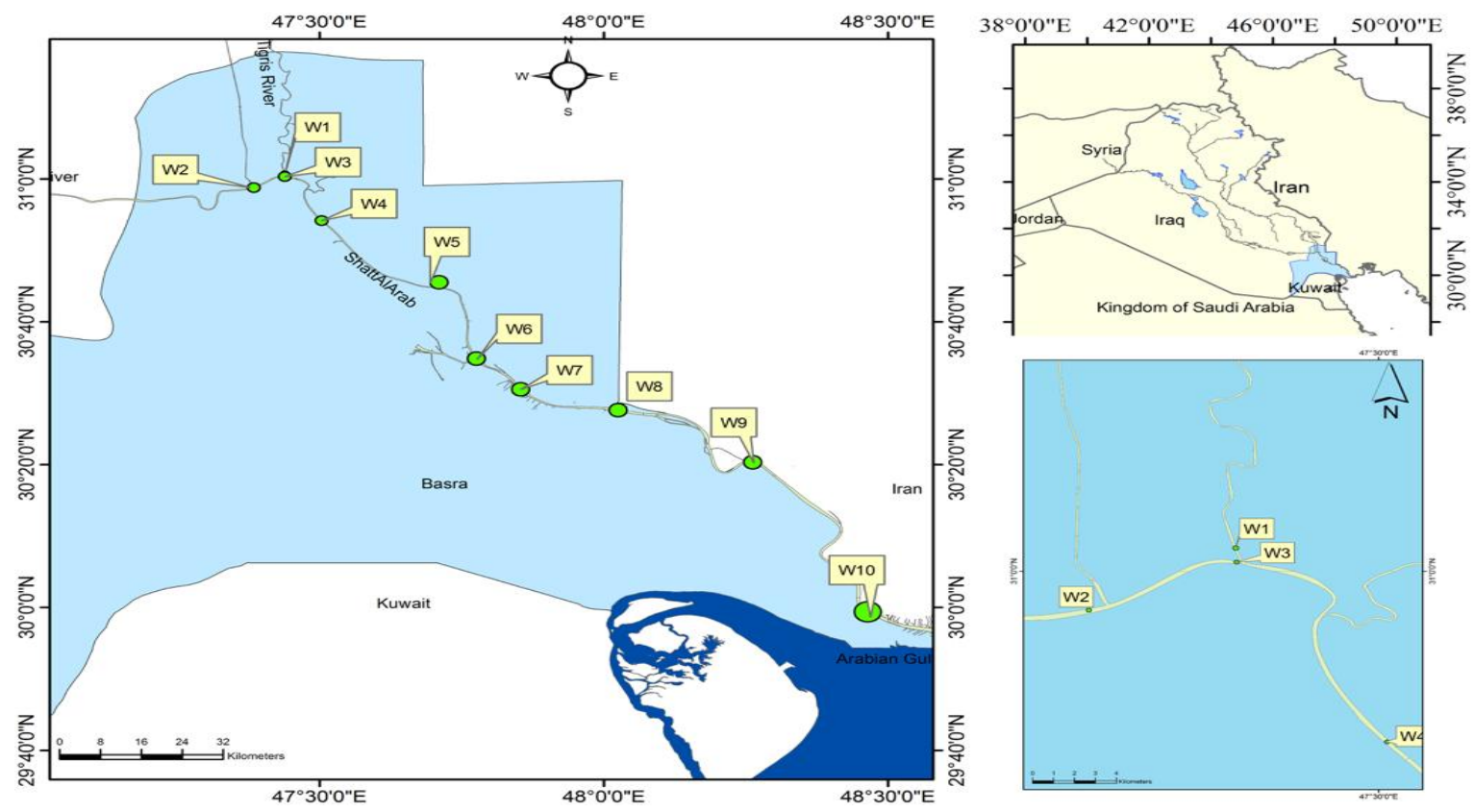

Fig 1. Locations of the samples selected in southern of Iraq

Tigris River $\left(\mathrm{W}_{1}\right)$ and two stations on Euphrates river $\left(\mathrm{W}_{2}, \mathrm{~W}_{3}\right)$, before the two rivers' confluence and form the Shatt Al-Arab River and another seven selected stations along Shatt Al-Arab River $\left(\mathrm{W}_{4}-\mathrm{W}_{10}\right)$. The importance of these regions lies in the various industrial and agricultural activities located along Shatt Al-Arab River as well as some activities like fishing by using toxic materials, navigation in the river and release of urban untreated effluents into the river $[1,6]$. All samples were collected by water sampler instrument at depth of $10-15 \mathrm{~cm}$ in the winter season, February of 2016, in various areas from surface water in low tide time and kept in dark glass bottles. These samples were preserved at $\mathrm{pH}=12$ by using sodium hydroxide and afterwards all samples were kept under cooling at $6{ }^{\circ} \mathrm{C}[12]$ and later transferred to the laboratory for carrying out different operations such as removal of different interferences that affect the accuracy of measurements of cyanide and digestion operations.

\section{Materials}

The list of chemical materials used in the procedure such as sodium acetate trihydrate $\mathrm{CH}_{3} \mathrm{COONa} \cdot 3 \mathrm{H}_{2} \mathrm{O}$ (99\%), pyridine $\mathrm{C}_{5} \mathrm{H}_{5} \mathrm{~N}$ (99\%) and sulfuric acid $\mathrm{H}_{2} \mathrm{SO}_{4}$ (97\%) was obtained from J.T. Baker. Glacial acetic acid $\mathrm{CH}_{3} \mathrm{COOH}$ (99.8\%) and hydrochloric acid $\mathrm{HCl}$ (37\%) were supplied by Scharlau. Chloroamine- $\mathrm{T}_{7} \mathrm{H}_{7} \mathrm{ClNNaO}_{2} \mathrm{~S}$ and potassium cyanide $\mathrm{KCN}$ were obtained from PubChem. Barbituric acid $\mathrm{C}_{4} \mathrm{H}_{4} \mathrm{~N}_{2} \mathrm{O}_{3}$ and sodium hydroxide $\mathrm{NaOH}$ were obtained from Himedia. Slphamic acid $\mathrm{H}_{3} \mathrm{NO}_{3} \mathrm{~S}$, lead carbonate $\mathrm{PbCO}_{3}$ and sodium thiosulfate $\mathrm{Na}_{2} \mathrm{~S}_{2} \mathrm{O}_{3}$ were supplied by B.D.H. Silver nitrate $\mathrm{AgNO}_{3}$, magnesium chloride hexahydrate $\mathrm{MgCl}_{2} \cdot 6 \mathrm{H}_{2} \mathrm{O}$ (99\%), potassium chloride $\mathrm{KCl}(99.5 \%)$ and potassium dichromate $\mathrm{K}_{2} \mathrm{Cr}_{2} \mathrm{O}_{7}$ (99.9\%) were supplied by Merck.

\section{Instrumentation}

All samples were collected by using a water sampler instrument from the surface water at depth of 10-15 cm in low tide and some physicochemical properties such as $\mathrm{pH}$, conductance, salinity, temperature of water, total dissolved solid TDS were measured directly in the field by multimeter type: WTW (Multi 3410 Set C, Germany). The concentration of free cyanide and total cyanide was measured by UV-Vis instrument type: Shimadzu double- beam UV-Vis spectrophotometer (model 1800 PC, Japan) with 1.0-cm quartz cell.

\section{Procedure}

After being collected, the samples were preserved at $\mathrm{pH}=12$ by using $1.0 \mathrm{M}$ of sodium hydroxide. $\mathrm{pH}$ was 
adjusted to 12 in order to prevent any interaction between sulfate and cyanide ions that occurs under $\mathrm{pH} 12$ that may later lead to the formation of thiocyanate ions. All samples were kept under cooling at $6{ }^{\circ} \mathrm{C}$ in dark glass bottles and then transferred to the laboratory in order to remove the oxidizing agents such as chlorine from the samples by using $0.1 \mathrm{~g}$ sodium thiosulfate $[2,12]$.

To determine the free cyanide concentration in all the samples, $40 \mathrm{~mL}$ of the alkaline sample was put in a $50 \mathrm{~mL}$ volumetric flask (air-tight) and $1 \mathrm{~mL}$ of buffer solution was added to it. The buffer solution was prepared from $\mathrm{CH}_{3} \mathrm{COONa} \cdot 3 \mathrm{H}_{2} \mathrm{O}$ and dissolved in glacial acetic acid. After that, $2 \mathrm{~mL}$ of chloroamine-T solution was added to the mixture and was left for $2 \mathrm{~min}$. Then, $5 \mathrm{~mL}$ from the mixture of pyridine-barbituric acid (this mixture was prepared by dissolving $15 \mathrm{~g}$ barbituric acid in $75 \mathrm{~mL}$ pyridine, and adding $15 \mathrm{~mL}$ of concentrated $\mathrm{HCl}$ and then complementing it to $250 \mathrm{~mL}$ with deionized water) were added to the solution and complemented to $50 \mathrm{~mL}$ with deionized water and left for $8 \mathrm{~min}[2,13]$. Finishing these steps, the sample was ready for analysis at $578 \mathrm{~nm}$ by using the UV-Vis spectrophotometer.

To determine the total cyanide concentration, a digestion operation had to be executed using a distillation method as the one described in the standard method [2]. Several materials such as sulfuric acid, sulphamic acid, lead carbonate and $\mathrm{MgCl}_{2} \cdot 6 \mathrm{H}_{2} \mathrm{O}$ were used in this method. After completing the digestion of the samples, the described method above was repeated.

In order to determine the concentration of free and total cyanide, the stock solution $(1000 \mathrm{mg} / \mathrm{L})$ must be prepared by using $\mathrm{KCN}$ and to obtain more accurate results a calibration of $\mathrm{KCN}$ standard material should be carried out. In this study the conductometric titration method was used by using silver nitrate, the silver nitrate was calibrated with potassium chloride and the potassium dichromate was used as an indicator. The concentration of $\mathrm{AgNO}_{3}$ was $880 \mathrm{mg} / \mathrm{L}$ after executing the calibration operation with potassium chloride. The calibration curve was obtained through the preparation of a series of $50 \mathrm{~mL}$ dilute solutions containing $0,0.02,0.1,0.25,0.5 \mathrm{mg} / \mathrm{L}$ of cyanide concentration and the same procedure was applied as described before for all the other samples. The result of the standard curve is shown in Fig. 2.

\section{- RESULTS AND DISCUSSION}

In order to obtain precise results, the conductometric titration method was used through the titration process between silver nitrate and $30 \mathrm{~mL}$ of potassium cyanide and measuring their conductivity after each addition of silver nitrate. The results of the conductometric titration method are shown in Fig. 3. This method is important for the calibration operation of the cyanide solution for it enables completing the calibration without using any indicator [14]. The results show that the concentration of the cyanide ion stock solution after carrying out the calibration operation was $997.33 \mathrm{mg} / \mathrm{L}$.

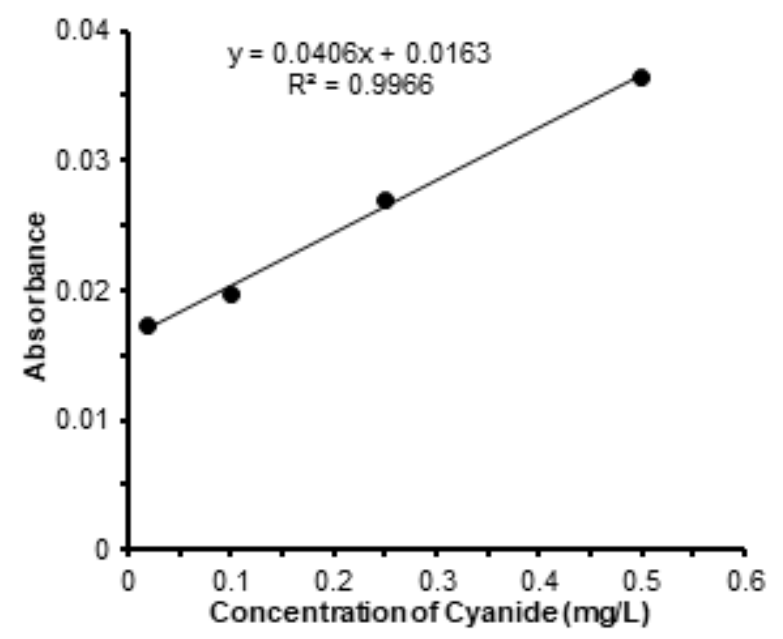

Fig 2. Standard curve of Cyanide solution

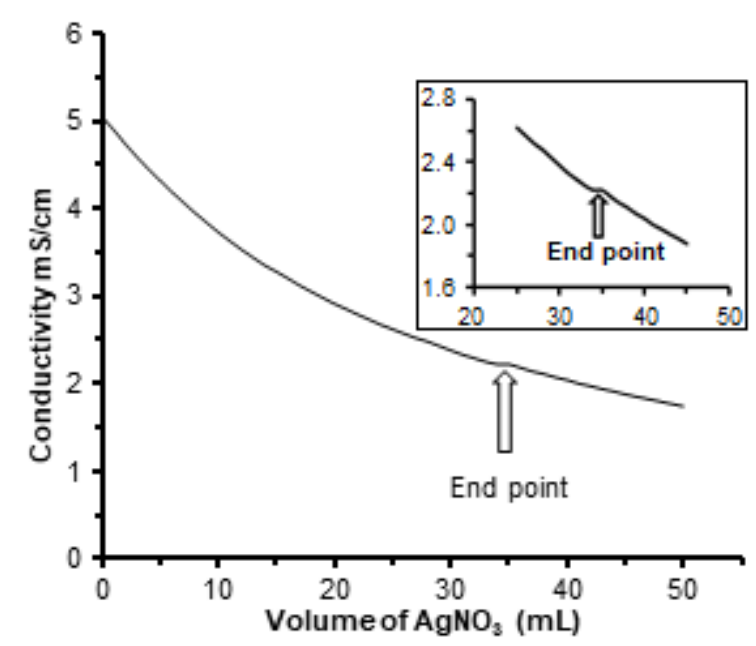

Fig 3. Calibration curve of Cyanide solution 
Some physicochemical properties were measured immediately in the field. These parameters are important for determining the quality of water and its effects on the aquatic system. All of the results of the physico-chemical properties measurements are shown in Table 1.

The $\mathrm{pH}$ of the water samples from various regions was recorded at 8.096-8.512 range. This refers to the behavior of alkali water due to the existence of different carbon compounds in waters such as carbon dioxide, carbonic acid, bicarbonate ions, and carbonate ions. These parameters are responsible for changing the $\mathrm{pH}$ value in aquatic systems. $\mathrm{pH}$ results of all the stations along Shatt Al-Arab River were compared between upstream and downstream. The highest $\mathrm{pH}$ value was recorded downstream in station $\mathrm{W}_{10}$. This may be due to the increase of concentrations from bicarbonate and carbonate salts in sea waters resulting from tides [2,15], on the other hand, the lowest $\mathrm{pH}$ value was recorded upstream in station $\mathrm{W}_{1}$ because this station has not undergone any anthropogenic activities. Moreover, the $\mathrm{pH}$ value was increased from stations $\mathrm{W}_{1}$ towards $\mathrm{W}_{4}$ upstream region. This might be attributed to the effect of low and high tide. At the same time, the decreased value of $\mathrm{pH}$ was noted in stations $\mathrm{W}_{4}$ to $\mathrm{W}_{7}$ due to the increase of the released untreated wastewater into the River [16]. $\mathrm{pH}$ results were compared with world regulations and were found to be within the acceptable limits of WHO 2011, EC 1998, CGL 2014 and the Iraqi standard 2001 for drinking waters [17-20]. The $\mathrm{pH}$ results are shown in Table 1.

The electrical conductivity, salinity and total dissolved solid are important for knowing the quality of water and its uses [16]. The measurements results of these parameters are shown in Table 1. The data obtained were in the ranges of 3010-6840 $\mu$ mhos $\mathrm{cm}^{-1}$, 1926.4-4377.6 mg/L and 1.5-3.7 ppt for electrical conductivity, total dissolved solid and salinity, respectively. The results were compared between the upstream and the downstream samples. The downstream samples showed high values, especially in station $\mathrm{W}_{10}$ because these regions are affected by different concentrations of salts from marine water through tide, whereas the upstream samples showed low values, especially in station $\mathrm{W}_{1}$ because there are no industrial or agricultural activities in this area.

The increase of salts concentration was noted from station $\mathrm{W}_{1}$ towards $\mathrm{W}_{5}$, with $\mathrm{W}_{5}$ having the highest concentration because in this region there are various industrial, agricultural and population activities. Moreover, the increase in salts concentration was also noted from station $\mathrm{W}_{5}$ towards station $\mathrm{W}_{7}$ because of the increase in population, industrial and agricultural activities. Additionally, the river navigation was high in

Table 1. Physico-chemical properties of selected water samples

\begin{tabular}{|c|c|c|c|c|c|c|c|}
\hline \multicolumn{2}{|c|}{$\begin{array}{l}\text { Sampling } \\
\text { locations }\end{array}$} & $\mathrm{pH}$ in field & $\begin{array}{l}\text { Temperature of } \\
\text { water }{ }^{\circ} \mathrm{C} \text { in field }\end{array}$ & $\begin{array}{l}\text { Salinity } \\
\text { ppt in field }\end{array}$ & $\begin{array}{c}\text { TDS } \\
\mathrm{mg} / \mathrm{L} \text { in field }\end{array}$ & $\begin{array}{c}\text { EC } \\
\mu \mathrm{mhos} \mathrm{cm}^{-1} \text { in field }\end{array}$ & $\begin{array}{c}\mathrm{EC} \\
\mu \mathrm{mhos} \mathrm{cm}^{-1} \text { at } 25^{\circ} \mathrm{C}\end{array}$ \\
\hline \multirow{5}{*}{ 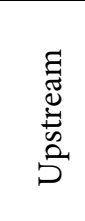 } & $\mathrm{W}_{1}$ & 8.096 & 13.7 & 1.5 & 1926.4 & 3010 & 3838.5 \\
\hline & $\mathrm{W}_{2}$ & 8.126 & 13.9 & 1.6 & 1971.2 & 3080 & 3908.7 \\
\hline & $\mathrm{W}_{3}$ & 8.135 & 13.8 & 1.6 & 1945.6 & 3040 & 3867.3 \\
\hline & $\mathrm{W}_{4}$ & 8.369 & 13.8 & 1.5 & 1939.2 & 3030 & 3854.6 \\
\hline & $\mathrm{W}_{5}$ & 8.325 & 14.1 & 1.8 & 2214.4 & 3460 & 4369.7 \\
\hline \multirow{5}{*}{ 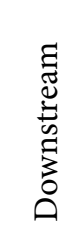 } & $\mathrm{W}_{6}$ & 8.267 & 15.7 & 3.2 & 3814.4 & 5960 & 7247.3 \\
\hline & $\mathrm{W}_{7}$ & 8.158 & 15.1 & 3.6 & 4288.0 & 6700 & 8262.3 \\
\hline & $\mathrm{W}_{8}$ & 8.201 & 13.7 & 3.5 & 4140.8 & 6470 & 8250.8 \\
\hline & $\mathrm{W}_{9}$ & 8.280 & 21.2 & 1.9 & 2297.6 & 3590 & 3870.9 \\
\hline & $\mathrm{W}_{10}$ & 8.512 & 14.9 & 3.7 & 4377.6 & 6840 & 8474.9 \\
\hline \multicolumn{2}{|c|}{ WHO 2011} & $6.5-8.5$ & - & - & 1000 & - & - \\
\hline \multicolumn{2}{|c|}{ CGL 2014} & $6.5-8.5$ & - & - & 500 & - & - \\
\hline \multicolumn{2}{|c|}{ EC 1998} & $6.5-9.5$ & 20 & - & 1500 & 2500 & 2763.958 \\
\hline \multicolumn{2}{|c|}{ IQS 2001} & $6.5-8.5$ & - & - & 1000 & - & - \\
\hline
\end{tabular}


this area because of the commercial port located nearby. Meanwhile, low salts concentration was noted from station $\mathrm{W}_{7}$ towards $\mathrm{W}_{9}$ because this region is affected by the flowrate of Karun River towards Shatt Al-Arab [16] in the nearby zone from station $\mathrm{W}_{9}$. The most important sources of salts concentration in aquatic systems are weathering of rocks, combustion of coal and oil, movement of wind, irrigation and drainage operations, rain water, domestic effluents and industrial waste [15-16].

The free cyanide of all the stations was measured using $\mathrm{Uv}$-Vis spectrophotometer at wavelength $578 \mathrm{~nm}$ through complex formation with pyridine-barbituric acid after the chlorination operation was executed by adding chloramine- $\mathrm{T}$ and a reddish color solution was formed. Free cyanide is a highly toxic species that can exist in the form $\mathrm{CN}^{-}$or $\mathrm{HCN}$. Moreover, released hydrocyanic acid increases in the aquatic system when the $\mathrm{pH}$ value is decreased to a value of about 5-6.5 [4,21]. The increase of cyanide concentration level in the water environment has many risks towards the quality of the aquatic system and thus it will negatively affect the human and animal health, especially in fish because it is able to accumulate in their organs $[1,22]$. The results of all the cyanide concentration measurements of the samples are shown in Table 2.
The highest value of free cyanide concentration in all the stations was recorded in the downstream regions, especially in station $W_{7}$. This might be due to the increase in population, industrial and agricultural activities [6,11]. Furthermore, this particular place is an important region for river navigation because of the commercial port located nearby. Meanwhile, stations $\mathrm{W}_{9}$ and $\mathrm{W}_{10}$ in the downstream regions and station $\mathrm{W}_{2}$ from the upstream region had not recorded any value of free cyanide concentration. This might be attributed to the decrease of the population activity in these regions. The concentration of free cyanide was also increased from station $\mathrm{W}_{1}$ towards $\mathrm{W}_{3}$ because these stations have undergone an increase of human activities, especially in station $\mathrm{W}_{3}$, whereas station $\mathrm{W}_{2}$ did not record any value of free cyanide that might be attributed to the decrease in human activities and increase of agricultural activities. In addition to that, the concentration value of free cyanide decreased in station $\mathrm{W}_{4}$ when compared with station $\mathrm{W}_{3}$ and once again the increase of free cyanide concentration was noted in station $\mathrm{W}_{5}$ because of the high population, industrial and agriculture activities. Likewise, the concentration of free cyanide was compared for all the measurements in the downstream

Table 2. Free and total cyanide concentration of all stations selected from surface water

\begin{tabular}{|c|c|c|c|c|c|}
\hline \multicolumn{2}{|c|}{ Sampling locations } & $\begin{array}{c}\text { Mean }(\mathrm{n}=3) \text { of Free } \\
\text { cyanide concentration } \mathrm{mg} / \mathrm{L}\end{array}$ & $\begin{array}{c}\text { Standard } \\
\text { Deviation }(\mathrm{SD})\end{array}$ & $\begin{array}{c}\text { Mean }(\mathrm{n}=3) \text { of Total } \\
\text { cyanide concentration } \mathrm{mg} / \mathrm{L}\end{array}$ & $\begin{array}{c}\text { Standard } \\
\text { Deviation (SD) }\end{array}$ \\
\hline \multirow{8}{*}{ 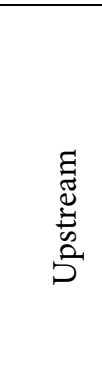 } & $\mathrm{W}_{1}$ & 0.036 & 0.007 & 0.207 & 0.010 \\
\hline & $\mathrm{W}_{2}$ & N.D & - & 4.253 & 0.042 \\
\hline & $\mathrm{W}_{3}$ & 0.222 & 0.048 & 0.357 & 0.031 \\
\hline & $\mathrm{W}_{4}$ & 0.019 & 0.007 & 9.022 & 0.003 \\
\hline & $\mathrm{W}_{5}$ & 0.160 & 0.031 & 4.631 & 0.032 \\
\hline & Average & 0.087 & 0.019 & 3.694 & 0.023 \\
\hline & $\mathrm{W}_{6}$ & 0.013 & - & 4.234 & 0.020 \\
\hline & $\mathrm{W}_{7}$ & 0.254 & 0.027 & 9.962 & 0.001 \\
\hline \multirow{4}{*}{ 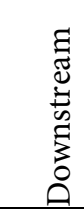 } & $\mathrm{W}_{8}$ & 0.109 & 0.007 & 6.271 & - \\
\hline & $\mathrm{W}_{9}$ & N.D & - & 3.944 & 0.004 \\
\hline & $\mathrm{W}_{10}$ & N.D & - & 4.758 & 0.013 \\
\hline & Average & 0.075 & 0.007 & 5.834 & 0.007 \\
\hline \multicolumn{2}{|c|}{ WHO 2011} & 0.17 & - & - & - \\
\hline \multicolumn{2}{|c|}{ CGL 2014} & 0.2 & - & - & - \\
\hline \multicolumn{2}{|c|}{ EPA 2009} & 0.2 & - & - & - \\
\hline \multicolumn{2}{|c|}{ IQS 2001} & 0.02 & - & - & - \\
\hline
\end{tabular}

N.D: Not Detected 
regions and it was noted that the concentration of free cyanide increased from station $\mathrm{W}_{6}$ towards $\mathrm{W}_{7}$. This might be due to population increase and the increase in industrial and agricultural activities. Additionally, the river navigation also increased in this area. Meanwhile, the concentration of free cyanide decreased from station $\mathrm{W}_{7}$ towards $\mathrm{W}_{10}$. When compared with other studies carried out in the Shatt Al-Arab environment, the data of this study were found to be consistent [23]. The results of the free cyanide concentration of all the stations were compared with several international regulation regarding permissible cyanide concentrations, namely WHO 2011, CGL 2014, IQS 2001 and EPA 2009 and the results of the current study have shown to be within the acceptable limits of EPA 2009 and CGL 2014. Meanwhile five stations have shown to be within the acceptable limits for IQS 2001. Additionally, two stations, $\mathrm{W}_{3}$ and $\mathrm{W}_{7}$ have recorded values that exceed the WHO 2011 allowed limits. The data for all the free cyanide measurements of the selected stations are shown in Table 2 .

Total cyanide concentration refers to the sum for all the cyanide ions that are involved in the structure of different compounds such as simple and complex compounds and also organic and inorganic compounds $[1,8]$. Total cyanide concentration of the selected samples for all the stations were measured through a digestion operation using the distillation method in acidic medium and by gas liberation of hydrocyanic acid. The gas was allocated later in alkaline solution and measured in UV-Vis spectrophotometer [2,12]. The results of all the measurements of the upstream region were in the range of $0.207-9.022 \mathrm{mg} / \mathrm{L}$ and the average of the concentrations for this region was $3.694 \mathrm{mg} / \mathrm{L}$. Meanwhile, the stations of the downstream region recorded higher concentrations of the total cyanide when compared with the upstream stations, in the range of 3.944-9.962 $\mathrm{mg} / \mathrm{L}$ and an average of $5.834 \mathrm{mg} / \mathrm{L}$. This might be attributed to the increase of industrial and population activities and also river navigation in these regions as well as the industrial waste and domestic untreated waste released into the river. The results of the total cyanide concentration are shown in Table 2. Generally, the most important sources that lead to the increase of the cyanide concentrations in water environment are the electroplating industry, gas extraction stations, combustion of coal and oil, movement of wind, irrigation and drainage operations, wastewater, industrial waste, metal processing, photographic processes, production of synthetic rubber, chemical synthesis, manufacture of plastics, pesticide/rodenticide control, laboratory processes and the manufacture of dyes and pigments [6-8,10,24].

\section{- CONCLUSION}

The current study has shown that cyanide concentration is present in the Shatt Al-Arab River environment that lead to many risks on human and animal's health. The results of the free cyanide concentrations were compared with several international regulations such as WHO 2011, CGL 2014, IQS 2001 and EPA 2009, where it showed values that exceed the permissible values in five stations when compared with IQS 2001 and thus lead to the increase of toxic properties in the aquatic system that can have a negative effecton human and animal's health. The results are consistent with Rasheed and Al-Imara study carried out in the Shatt Al-Arab environment that used cyanide selective electrode method for measurement. Meanwhile the total cyanide concentration has shown the highest values in all stations when compared with all the allowed limits globally.

\section{- REFERENCES}

[1] Zheng, A., Dzombak, D.A., Luthy, R.G., Sawyer, B., Lazouskas, W., Tata, P., Delaney, M.F., Zilitinkevitch, L., Sebroski, J.R., Swartling, R.S., Drop, S.M., and Flaherty, J.M., 2003, Evaluation and testing of analytical methods for cyanide species in municipal and industrial contaminated waters, Environ. Sci. Technol., 37 (1), 107-115.

[2] American Public Health Association, American Water Works Association, Water Environment Federation, 1999, Standard Methods for the examination of water and wastewater, $20^{\text {th }} \mathrm{Ed}$., APHA, AWWA, WEF, Washington DC.

[3] Owuamanam, C.I., Iwouno, J.O., Ihediohanma, N.C., and Barber, L.I., 2010, Cyanide reduction, functional and sensory quality of gari as affected by 
$\mathrm{pH}$, temperature and fermentation time, Pak. J. Nutr., 9 (10), 980-986.

[4] Razanamahandry, L.C., Karoui, H., Andrianisa, H.A., and Yacouba, H., 2017, Bioremediation of soil and water polluted by cyanide: A review, Afr. J. Environ. Sci. Technol., 11 (6), 272-291.

[5] Chueachot, R., and Chanthai, S., 2014, Spectrophotometric determination of trace cyanide in fruit wines by the catalytic reaction of ninhydrin following micro-distillation, Orient. J. Chem., 30 (1), 119-131.

[6] Gijzen, H.J., Bernal, E., and Ferrer, H., 2000, Cyanide toxicity and cyanide degradation in anaerobic wastewater treatment, Water Res., 34 (9), 2447-2454.

[7] Mansfeldt, T., and Biernath, H., 2000, Determination of total cyanide in soils by micro-distillation, Anal. Chim. Acta, 406 (2), 283-288.

[8] Osobamiro, M.T., 2012, Determination of the concentration of total cyanide in waste water of a tobacco company in Southwestern Nigeria, J. Appl. Sci. Env. Manage., 16 (1), 61-63.

[9] Gensemer, R.W., Deforest, D.K. Cardwell, R.D., Dzombak, D., Santore, R., and Stewart, M., 2006, Reassessment of cyanide ambient water quality criteria: An integrated approach to the protection of the aquatic environment, Presentation at the SETAC North America $27^{\text {th }}$ Annual Meeting, Montreal, Canada.

[10] Obiri, S., Dodoo, D.K., Okai-Sam, F., and Essumang, D.K., 2007, Determination of free cyanide and total cyanide concentrations in surface and underground waters in Bogoso and its surrounding areas in Ghana, Bull. Chem. Soc. Ethiop., 21 (2), 213-220.

[11] Delaney, M.F., and Blodget, C., 2015, Total cyanide field spikes for industrial wastewater samples verify successful sample integrity, preservation, pretreatment and testing, Water Environ. Res., 87 (6), 559-566.

[12] Gautam, S.P., 2011, Guide manual: Water and wastewater analysis, Central Pollution Control Board, Ministry of Environment and forests, India.

[13] United States Environmental Protection Agency (EPA), 1996, Titrimetric and manual spectrophotometric determinative methods for cyanide, Method 9014.

[14] Raj, G., 2008, Advanced Practical Inorganic Chemistry, $20^{\text {th }}$ Ed., Krishna Prakashan Media, India.

[15] Abdulnabi, Z.A., 2016, Assessment of some toxic elements levels in Iraqi marine water, Mesopot. J. Mar. Sci., 31 (1), 85-94.

[16] Abdulnabi, Z.A., Hassan, W.F., Al-Khuzaie, D.K.K., Saleh, S.M., and Hashim, M.G., 2015, Evaluation of selenium levels for the water surfaces in southern Iraq, J. Chem. Pharm. Res., 7 (10), 495-501.

[17] WHO, 2011, Guidelines for drinking water quality, $4^{\text {th }}$ Ed., Switzerland.

[18] Directive 98/83/EC, 1998, Council Directive 98/83/EC of 3 November 1998 on the quality of water intended for human consumption, Official Journal of the European Communities, L330, 32-54.

[19] Health Canada, 2014, Guidelines for Canadian drinking water quality-Summary table, Water and Air Quality Bureau, Healthy Environments and Consumer Safety Branch, Health Canada, Ottawa, Ontario.

[20] IQS, 2001, Standard no. 417 on drinking water and analysis-Standard specification for drinking water, Central Organization for Quality Control and Standardization, Council of Ministers, Republic of Iraq.

[21] United States Environmental Protection Agency (EPA), 1980, Cyanide, total (titrimetric, spectrophotometric), Technical Revision, NERL Method 335.2.

[22] Hassan, D.M.A., and Farghali, M.R.F., 2018, Cyanide pollution in different water sources in Assiut, Egypt: Levels, distributions, and health risk assessment, Res. J. Environ. Sci., 12 (5), 213-219.

[23] Rasheed, B.A., and Al-Imarah, F.J.M., 2014, Temporal and spatial distribution of cyanide ion in Southern Iraqi waterways, Int. J. Environ. Water, 3 (5), 207-212.

[24] Environment and Climate Change Canada, Health Canada, 2018, Risk management scope for cyanides, Government of Canada. 